\title{
Incidence and quality of root canal fillings in undergraduate dental students
}

\author{
Incidência e qualidade de obturações de canais radiculares \\ em estudantes de graduação em Odontologia
}

\author{
Beethoven Estevão COSTA ${ }^{1}$ iD 0000-0002-4274-2833 \\ Giovanna Morais de LIMA' ${ }^{1}$ 0000-0001-5080-7505 \\ Stéphanie Quadros TONELLI² (iD 0000-0002-4671-9868 \\ Eduardo NUNES² (iD) 0000-0002-9508-3640 \\ Frank Ferreira SILVEIRA ${ }^{1,2}$ iD 0000-0002-4298-0540
}

\section{ABSTRACT}

Objective: The purpose of this study was to evaluate the incidence of endodontic treatment and the quality of root canal fillings in Brazilian undergraduate dental students. The study was similar those conducted 10, 20, 30, and 40 years earlier. Methods: A total of 407 undergraduate dental students were evaluated by using questionnaires to identify endodontic treatments, with each treatment being radiographed for the analysis of the presence of a periapical radiolucency and the quality of the root canal filling. Results: Forty root canal fillings were found: 32 (80\%) completely filled, seven (17.5\%) incompletely filled, and one (2.5\%) overfilled. Conclusion: This study showed a low prevalence of endodontic treatment in dentistry students, and the evaluated root canals that were filled were high quality, with few cases suggesting periapical lesions.

Indexing terms: Dental students. Endodontics. Endodontic treatment. Root canal filling. Radiography.

\section{RESUMO}

Objetivo: O objetivo deste estudo foi avaliar a incidência do tratamento endodôntico e a qualidade das obturações de canais radiculares numa população de estudantes de odontologia brasileiros. O estudo foi semelhante a estudos prévios realizados há 10, 20,30 e 40 anos. Métodos: Um total de 407 estudantes de odontologia foi avaliado por meio de questionários para identificação de tratamentos endodônticos, sendo cada tratamento radiografado para a análise da presença de radioluscência periapical e a qualidade da obturação endodôntica. Resultados: Foram encontrados 40 canais radiculares obturados, sendo 32 (80\%) com adequada obturação, sete $(17,5 \%)$ com subobturação e um (2,5\%) sobreobturado. Conclusão: Este estudo mostrou uma baixa prevalência de tratamento endodôntico em estudantes de odontologia, e os tratamentos avaliados apresentaram alta qualidade, com poucos casos sugerindo lesões periapicais.

Termos de indexação: Estudantes de Odontologia. Endodontia. Obturação do canal radicular. Radiografia. Tratamento endodôntico.

$\because \mathrm{Vr}$

1 Universidade de Itaúna, Faculdade de Odontologia. Itaúna, MG, Brasil.

2 Pontifícia Universidade Católica de Minas, Departamento de Odontologia. Av. Dom José Gaspar, 500, prédio 46, 30535610, Coração Eucarístico, Belo Horizonte, MG, Brasil. Correspondência para / Correspondence to: FF SILVEIRA. E-mail: <frankfoui@uol.com.br>.

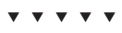

Costa BE, Lima GM, Tonelli SQ, Nunes E, Silveira FF. Incidência e qualidade de obturações de canais radiculares em estudantes de graduação em Odontologia. RGO, Rev Gaúch Odontol. 2019;67:e20190057. http://dx.doi.org/10.1590/1981-863720190005720180088 


\section{INTRODUCTION}

Endodontic treatment is performed based on a series of factors and steps that when well conducted are aimed at reducing the chances of failure and accidents [1-3]. A correct radiographic interpretation, the technique employed, the use of suitable materials, and the ability of the operator directly interfere with the success or failure of the treatment. Failure can result from inadequate access, perforations, instrument fractures, overfilling, and incomplete fillings [1-5].

To evaluate the success or failure of endodontic treatment, clinical and radiographic methods were used in the past. Failures could be identified by an increase in the thickness of the periodontal ligament; the absence of bone repair within the lesion, or an increase in the size of rarefaction; the absence of the formation of a new hard blade; the appearance of bone rarefaction in areas that previously did not exist; unfilled spaces that are visible in the canal, apically or laterally associated with periapical lesions; and active resorptions associated with other radiographic signs [2-7].

A systematic review of cross-sectional studies showed that the prevalence of a periapical radiolucency was very high, broadly equivalent to one radiolucency per patient, and the prevalence of teeth with root canal treatment was very high, too, broadly equivalent to two treatments per patient [8]. In the literature, many studies showed concern about this issue. Comparing the results of epidemiological studies (table 1), we observed the high occurrence of inadequate endodontic treatment in several populations, as well as the radiographic suggestion of a periapical reaction.

Table 1. Summary of endodontic epidemiological studies.

\begin{tabular}{|c|c|c|c|c|c|c|c|}
\hline Authors & Population & Patients (n) & Teeth $(n)$ & $\operatorname{RTF}(n)$ & Prevalence RFT (\%) & PR in RFT (\%) & IF $(\%)$ \\
\hline Cleen et al. ${ }^{9}$ & Dutch & 184 & 4196 & 97 & 2,3 & 6 & 50,6 \\
\hline Buckley \& Spångberg ${ }^{10}$ & American & 208 & 5272 & 291 & 5,5 & 31,1 & 42 \\
\hline Weiger et al. ${ }^{11}$ & German & 323 & 7897 & 215 & 2,7 & 61 & 86 \\
\hline Sidaravicius et al. ${ }^{12}$ & Lithuania & 147 & 3892 & 586 & 15 & 35 & 36,4 \\
\hline De Moor et al. ${ }^{13}$ & Belgian & 206 & 4617 & 314 & 6,8 & 40,4 & 56,7 \\
\hline Boucher et al. ${ }^{14}$ & French & 208 & 5373 & 1026 & 19,1 & 27 & 29,7 \\
\hline Lupi-Pegurier et al. ${ }^{16}$ & French & 344 & 7561 & 1429 & 18,9 & 31,5 & 68,8 \\
\hline Kabak \& Abbott ${ }^{16}$ & Belarusian & 1423 & 31312 & 6339 & 20 & 45 & 52,3 \\
\hline Loftus et al. ${ }^{17}$ & Irish & 302 & 7427 & 149 & 2 & 25 & 52,6 \\
\hline Peciuliene et al. ${ }^{18}$ & Unspecific & 83 & 2186 & 283 & 13 & 43,1 & 71,4 \\
\hline Sunay et al. ${ }^{19}$ & Turkish & 375 & 8863 & 470 & 5,3 & 53,5 & 91 \\
\hline Asgary et al. ${ }^{20}$ & Iranian & 1064 & 28463 & 1013 & 3,5 & 52 & 57,7 \\
\hline Covello et al. ${ }^{21}$ & Italian & 384 & 9423 & 1076 & 11,41 & 41,6 & 59,48 \\
\hline Kamberi et al. ${ }^{22}$ & Kosovar & 193 & 4131 & 95 & 2,3 & 12,3 & 46,3 \\
\hline Matijević et al. ${ }^{23}$ & Croatian & 1462 & 38440 & 3279 & 8,53 & 8,5 & 66,8 \\
\hline Özbaş et al. ${ }^{24}$ & Turkish & 438 & 11542 & 179 & 1,55 & 37,99 & 77,95 \\
\hline Peters et al. ${ }^{25}$ & Dutch & 178 & 4594 & 224 & 4,8 & 24,1 & 55,8 \\
\hline Mukhaimer et al. ${ }^{26}$ & Palestine & 258 & 6482 & 855 & 1,31 & 15,1 & 74,5 \\
\hline Jersa \& Kundzina ${ }^{27}$ & Riga & 312 & 7065 & 1255 & 17,76 & 31 & 77,29 \\
\hline Ureyen Kaya et al. ${ }^{28}$ & Turkish & 1000 & 23268 & 753 & 2,6 & 15,8 & 59 \\
\hline Di Filippo et al. ${ }^{29}$ & London & 136 & 3396 & 115 & 3,38 & 38,7 & 44,3 \\
\hline Ilić et al. $(2014)^{30}$ & Serbian & 153 & 3526 & 440 & 12,5 & 51,8 & 55,9 \\
\hline Kirkevang et al. ${ }^{31}$ & Danish & 327 & 8666 & 404 & 12 & 42 & 75 \\
\hline Archana et al. ${ }^{32}$ & Indian & 1340 & 30298 & 1234 & 4,07 & 37,4 & 61,7 \\
\hline Oginni et al. ${ }^{33}$ & Nigerian & 756 & 21468 & 2597 & 12,2 & 41 & 40 \\
\hline Mean of studies & - & 472,16 & 11574 & 988 & 8,34 & 34 & 59,56 \\
\hline
\end{tabular}


In this context, some studies evaluated endodontic treatment and its quality in university students, with a high prevalence of poorly filled canals $[6,8]$. With the constant evolution of technologies and concern with the maintenance of the aseptic chain, to study the prevalence situation of endodontic treatment in the university population, evaluating the success rate of any treated teeth seems to be appropriate $[3,4]$.

The present study's aim was to analyze the prevalence of endodontic treatment as well as the quality of filled teeth and periapical status in a Brazilian subpopulation of dental students, taking into consideration other studies conducted 10, 20,30, and 40 years ago along the same lines.

\section{METHODS}

This study received approval from the local institutional review board (CAAE: 01958818.4.0000.5137). A total of 407 students who were enrolled in the dentistry graduation course in our university were evaluated through questionnaires aimed at identifying students with endodontically treated teeth. The questionnaire included questions about dental history, related to the presence of endodontic treatment or the lack thereof, its cause, and when it was performed, as well as the number of teeth remaining, excluding third molars. The participation in this research was conditioned to the previous signing of an informed consent form.

After the presence of endodontically treated teeth was identified, the students were submitted to digital radiographic examination for further evaluation of the quality of the treatment performed.

Radiographs were performed and revealed 23 root-filled teeth (RFT), with 40 roots in total evaluated. The roots were categorized into three groups according to the quality of the root canal filling parameters [34]:

- Completely filled canal: filling performed 0.5 to $1.5 \mathrm{~mm}$ from the radiographic apex and without voids in the obturator body

- Incompletely filled canal: filling performed 2.0 $\mathrm{mm}$ or more from the radiographic vertex with empty spaces in the obturator body

- Overfilled canal: filling at or above the radiographic apex
For each of the three variables, the presence or absence of periapical reaction evidenced by radiography was evaluated [35]. The data were tabulated and analyzed in Microsoft Excel for Windows (Microsoft, Redmond, Washington, USA) via descriptive statistics (mean and percentage).

\section{RESULTS}

In this study's subpopulation of 407 individuals, 15 subjects $(3.68 \%)$ had endodontically treated teeth. A total of 10,582 teeth were analyzed, and the prevalence of teeth with endodontic treatment was $0.2 \% \quad(n=23)$. According to Table 2, we founded all 40 filled canals.

Throughout our sample, we found only two canals filled with periapical radiolucencies. The number and percentage of completely, incompletely, and overfilled canals, as well as the presence or absence of periapical reaction were recorded (Table 2). Representative cases of each of the conditions found can be visualized in Figure 1.

\section{DISCUSSION}

Studies investigating the prevalence of endodontic treatments, as well as their technical quality and the occurrence of apical periodontitis are important for increasing endodontic epidemiology $[9,33]$. Particularly, some studies have been carried out during the past few decades through radiographic evaluation in dentistry students to verify the quality of endodontic treatment,

Table 2. Radiographic survey of endodontic treatment in dentistry students.

\begin{tabular}{lcc}
\hline & $\mathrm{n}$ & $\%$ \\
\hline Treated root canals & 40 & $100 \%$ \\
Completely filled & 32 & $80 \%$ \\
With periapical reaction & 0 & $0 \%$ \\
No periapical reaction & 32 & $100 \%$ \\
Incompletely filled & 7 & $17.5 \%$ \\
With periapical reaction & 2 & $28.57 \%$ \\
No periapical reaction & 5 & $71.43 \%$ \\
Over-filled & 1 & $2.5 \%$ \\
With periapical reaction & 0 & $0 \%$ \\
No periapical reaction & 1 & $100 \%$ \\
\hline
\end{tabular}




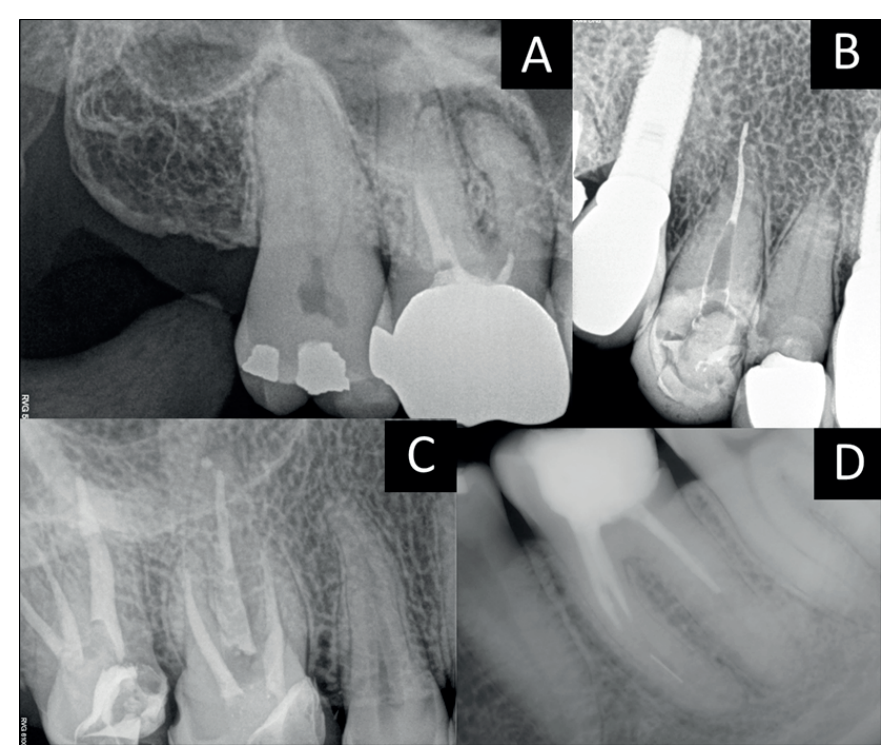

Figure 1. Representative of each of the conditions detected. A - Incompletely filled canal with presence of radioluscence; B - Overfilled canal with absence of radioluscence; $\mathrm{C}$ - Completely filled canal with absence of radioluscence; D - - Incompletely filled canal with absence of radioluscence.

observing the quality of treated teeth, as well as the success or failure of the treatment $[8,11]$.

Our sample showed a low occurrence of endodontic treatment and periapical radiolucencies compared with all studies described in table 1 . This could be due to the fact that our sample was made up of students, mostly young adults. Nevertheless, the occurrence of periapical reactions (20\%) was greater than or compatible with that of some previous studies $[9,23,26,28]$.

To systematize and match the discussion, the present study selected similarly themed investigations that considered Brazilian populations and dental students. The existence of these studies in the literature motivated us to choose this population (Brazilian dentistry students), which also made access and data collection easier. In 1972, dental students of the Dental School of UNESP, Araraquara, São Paulo State, Brazil, were examined, and it was found that $67.3 \%$ of root canals had inadequate fillings after radiographic analysis, and $70.4 \%$ had periapical reactions [36]. Also, in 1972, a similar work including dental students at the University of Uberlândia, Minas Gerais, Brazil, observed $90.1 \%$ root canals with inadequate fillings and $62.1 \%$ with chronic periapical reactions [37]. Sixteen years later, a survey at the abovementioned two colleges, funded in Araraquara, revealed $65.54 \%$ of root canals with incomplete fillings and $40 \%$ with periapical reactions. In Uberlândia, the prevalence was $60.26 \%$ for deficient fillings and $44.7 \%$ for periapical reactions [37]. Through this comparison, a large fall in the percentage of poorly obtained root canals was observed, but the authors considered the results to still be alarming, taking into account the population segment involved students of higher education [37].

In a comparative analysis with the results obtained from various authors, a re-duction in the number of failed fillings was observed $[8,40]$. In 1988, an improvement in the quality of endodontic treatment was detected between 1969 and 1984 [41]. It was observed that in the late 1960 s, the percentage of poorly performed treatments was $83 \%$, and after the 1980 s, this percentage fell to $64.25 \%$. This shows a fall in the percentage over the past few years [41].

In 2003, a study analyzed the teeth submitted to endodontic treatment for a minimum period of two years, based on periapical radiography, with the objective of evaluating the degree of success and failure of the endodontic treatment [5]. The results showed that $78.9 \%$ of the endodontic treatments performed had successes, concluding that there was a huge statistical difference between the percentages of success and failure [5]. In 2002, a study conducted at the School of Dentistry of the University of Itaúna analyzed filled root canals, wherein $54.3 \%$ presented deficient fillings and $36.3 \%$ periapical reactions [42]. In the present study, of the total of 40 root canals treated, 7 (17.5\%) werw incompletely filled, two $(28.57 \%)$ with periopical reactions, and one $(2.5 \%)$ was overfilled without radiographically visible periapical reaction.

One of the limitations of the present study is the initial selection of the presence of endodontic treatments through a self-administered questionnaire, which may have led to the omission of some data due to participants' memory bias. However, in the best of our conclusions, we showed a low occurrence of endodontic treatment in the investigated population, as well as a significant improvement in the quality of endodontic treatment compared with previous studies. These results are possibly a response to the great advances of endodontics, with the advent of improvements in equipment for instrumentation, filling, and diagnostics, in addition to the great current concern with the maintenance of the aseptic chain. 


\section{CONCLUSION}

This study showed a low prevalence of endodontic treatment in dentistry students, and the evaluated filled root canals were high quality, with few cases suggesting periapical lesions.

\section{Collaborators}

BE COSTA and GM LIMA contributed in the collecting data and writing phase, SQ TONELLI and E NUNES contributed in the writing phase and data analysis, FF SILVEIRA collaborated in the design of the study, collecting data and written review.

\section{REFERENCES}

1. Ricucci D, Siqueira-Jr JF. Biofilms and apical periodontitis: study of prevalence and association with clinical and histopathologic findings. J Endod. 2010;36(8):1277-1288. https://doi:10.1016/j.joen.2010.04.007

2. Toubes KM, Tonelli SQ, Oliveira BJ, Duarte G, Nunes E, Silveira FF. Apical periodontitis associated with a calculus-like deposit: A case report of a rare fan-shaped manifestation. Ann Med Surg (Lond). 2019;21(41):1-5. https://doi:10.1016/j. amsu.2019.03.003

3. Barrieshi-Nusair KM, Al-Omari MA, Al-Hiyasat AS. Radiographic technical quality of root canal treatment performed by dental students at the Dental Teaching Center in Jordan. J Dent. 2004;32(4):301-307. https://doi:10.1016/j. jdent.2004.01.002

4. Benenati FW, Khajotia SS. A radiographic recall evaluation of 894 endodontic cases treated in a dental school setting. J Endod. 2002;28(5):391-395. https:// doi:10.1097/00004770200205000-00011

5. Kamaura D, Carvalho GL, Lage-Marques JL, Antoniazzi JH. Avaliação do desempenho dos alunos de graduação durante a prática da técnica endodôntica. Rev Abeno. 2003;3(1):33-40.

6. Pontes ALB, Machado FCA, Costa APS, Noro LRA, Araujo ME, Ferreira MAF. Avaliação da Qualidade dos Tratamentos Endodônticos em Centros de Especialidades Odontológicas da Grande Natal - RN. Pesq Bras Odontoped Clin Integr. 2013;13(2):155-160. https://doi:10.4034/PBOCl.2013.132.03

7. Bonetti Filho I, Leonardo MR, Leal JM, Esberard RM, Simões Filho AP, Marçal P. Avaliação dos tratamentos endodônticos: verificação radiográfica em universitários das Faculdades de Odontologia de Araraquara/SP (UNESP) e de Uberlândia/MG (UFU). RGO 1988;36(4):309-312.

8. Pak JG, Fayazi S, White SN. Prevalence of periapical radiolucency and root canal treatment: a systematic review of cross-sectional studies. J Endod. 2012;38(9):1170-1176. https://doi:10.1016/j.joen.2012.05.023
9. De Cleen MJ, Schuurs AH, Wesselink PR, Wu MK. Periapical status and prevalence of endodontic treatment in an adult Dutch population. Int Endod J. 1993;26(2):112-9. https:// doi:10.1111/j.1365-2591.1993.tb00552.x

10. Buckley M, Spångberg LS. The prevalence and technical quality of endodontic treatment in an American subpopulation. Oral Surg Oral Med Oral Pathol Oral Radiol Endod. 1995;79(1):92100. https://doi:10.1016/s1079-2104(05)80081-2

11. Weiger R, Hitzler S, Hermle G, Löst C. Periapical status, quality of root canal fillings and estimated endodontic treatment needs in an urban German population. Endod Dent Traumatol. 1997;13(2):69-74. https://doi:10.1111/j.1600-9657.1997. tb00013.x

12. Sidaravicius B, Aleksejuniene J, Eriksen HM. Endodontic treatment and prevalence of apical periodontitis in an adult population of Vilnius, Lithuania. Endod Dent Traumatol. 1999;15(5):210-215. https://doi:10.1111/j.1600-9657.1999. tb00776.x

13. De Moor RJ, Hommez GM, De Boever JG, Delmé KI, Martens GE. Periapical health related to the quality of root canal treatment in a Belgian population. Int Endod J. 2000;33(2):113-120. https://doi:10.1046/j.1365-2591.2000.00295.x

14. Boucher Y, Matossian L, Rilliard F, Machtou P. Radiographic evaluation of the prevalence and technical quality of root canal treatment in a French subpopulation. Int Endod J. 2002;35(3):229-238. https://doi:10.1046/j.1365-2591.2002. 00469.x

15. Lupi-Pegurier L, Bertrand MF, Muller-Bolla M, Rocca JP, Bolla M. Periapical status, prevalence and quality of endodontic treatment in an adult French population. Int Endod $\mathrm{J}$. 2002;35(8):690-697. https://doi:10.1046/j.1365-2591.2002. 00547.x

16. Kabak Y, Abbott PV. Prevalence of apical periodontitis and the quality of endodontic treatment in an adult Belarusian population. Int Endod J. 2005;38(4):238-245. https:// doi:10. 1111/j.1365-2591.2005.00942.x

17. Loftus JJ, Keating AP, McCartan BE. Periapical status and quality of endodontic treatment in an adult Irish population. Int Endod J. 2005;38(2):81-86. https:// doi:10.1111/j.1365-25 91.2004.00902.x

18. Peciuliene $V$, Rimkuviene J, Maneliene R, Ivanauskaite D. Apical periodontitis in root filled teeth associated with the quality of root fillings. Stomatologija. 2006;8(4):122-126. https:// doi:10.1007/978-3-319-57250-5

19. Sunay H, Tanalp J, Dikbas I, Bayirli G. Cross-sectional evaluation of the periapical status and quality of root canal treatment in a selected population of urban Turkish adults. Int Endod J. 2007;40(2):139-145. https:// doi:10.1111/j.1365-25 91.2007.01217.x

20. Asgary S, Shadman B, Ghalamkarpour Z, Shahravan A, Ghoddusi J, Bagherpour A, et al. Periapical Status and Quality of Root canal fillings and coronal restorations in Iranian population. Iran Endod J. 2010;5(2):74-82.

21. Covello F, Franco V, Schiavetti R, Clementini H, Mannocci Um, Ottria $G$, et al. Prevalence of apical periodontitis and quality of endodontic treatment in an Italian adult population. Implantol Oral (Roma). 2010;3(4):9-14. 
22. Kamberi B, Hoxha V, Stavileci M, Dragusha E, Kuçi A, Kqiku L. Prevalence of apical periodontitis and endodontic treatment in a Kosovar adult population. BMC Oral Health. 2011;11(32):16. https://doi:10.1186/1472-6831-11-32.

23. Matijević J, Cizmeković Dadić T, Prpic Mehicic G, Ani I, Slaj M, Jukić Krmek S. Prevalence of apical periodontitis and quality of root canal fillings in population of Zagreb, Croatia: a crosssectional study. Croat Med J. 2011;52(6):679-687. https:// doi:10.3325/cmj.2011.52.679

24. Özbaş H, Aşcı S, Aydın Y. Examination of the prevalence of periapical lesions and technical quality of endodontic treatment in a Turkish subpopulation. Oral Surg Oral Med Oral Pathol Oral Radiol Endod. 2011;112(1):136-142. https:// doi:10.1016/j.tripleo.2011.01.010.

25. Peters LB, Lindeboom JA, Elst ME, Wesselink PR. Prevalence of apical peri-odontitis relative to endodontic treatment in an adult Dutch population: a re-peated cross-sectional study. Oral Surg Oral Med Oral Pathol Oral Radiol En-dod. 2011;111(4):523-8. https://doi:10.1016/j.tripleo.2010.10.035.

26. Mukhaimer R, Hussein E, Orafi I. Prevalence of apical periodontitis and quali-ty of root canal treatment in an adult Palestinian sub-population. Saudi Dent J. 2012;24(3-4):149-155. https://doi:10.1016 / j.sdentj.2012.02.001.

27. Jersa I, Kundzina R. Periapical status and quality of root fillings in a selected adult Riga population. Stomatologija. 2013;15(3):73-77

28. Ureyen Kaya B, Kececi AD, Guldas HE, Orhan H. A retrospective radiographic study of coronal-periapical status and root canal filling quality in a selected adult Turkish population. Med Princ Pract. 2013;22(4):334-339. https://doi:10.1159/000346940

29. Di Filippo G, Sidhu SK, Chong BS. Apical periodontitis and the technical quality of root canal treatment in an adult subpopulation in London. Br Dent J. 2014;216(10):E22. https:// doi:10.1038/sj.bdj.2014.404

30. Ilić J, Vujašković M, Tihaček-Šojić L, Milić-Lemić A. Frequency and quality of root canal fillings in an adult Serbian population. Srp Arh Celok Lek. 2014;142(11-12):663-668.

31. Kirkevang LL, Vaeth M, Wenzel A. Ten-year follow-up of root filled teeth: a ra-diographic study of a Danish population. Int Endod J. 2014;47(10):980-988. https://doi:10.1111/iej.12245

32. Archana D, Gopikrishna V, Gutmann JL, Savadamoorthi KS, Kumar AR, Na-rayanan LL. Prevalence of periradicular radiolucencies and its association with the quality of root canal procedures and coronal restorations in an adult urban
Indian population. J Conserv Dent. 2015;18(1):34-38. https:// doi:10.4103 / 0972-0707.148888

33. Oginni AO, Adeleke AA, Chandler NP. Root canal treatment and prevalence of apical periodontitis in a nigerian adult subpopulation: a radiographic study. Oral Health Prev Dent. 2015;13(1):85-90. https://doi:10.3290/j.ohpd.a31661

34. Santos SM1, Soares JA, Costa GM, Brito-Júnior M, Moreira AN, de Magalhães CS. Radiographic parameters of quality of root canal fillings and periapical status: a retrospective cohort study. J Endod. 2010;36(12):1932-1937. https:// doi:10.1016/j.joen.2010.08.050

35. Santos SM, Soares JA, César CA, Brito-Júnior M, Moreira AN, Magalhães CS. Radiographic quality of root canal fillings performed in a postgraduate pro-gram in endodontics. Braz Dent J. 2010;21(4):315-321. https://doi:10.1590/s010364402010000400005

36. Leal JM, Leonardo MR, Simões Filho AP. Avaliação clínica e radiográfica dos tratamentos endodônticos verificados nos universitários da Faculdade de Farmácia e Odontologia de Araraquara/SP. IV Congresso Paulista de Endodontia, Guarujá, SP, 1972.

37. Leonardo MR, Marçal P. Avaliação clínica e radiográfica de canais radiculares em universitários da Faculdade de Odontologia de Uberlândia/MG. IV Congresso Paulista de Endodontia, Guarujá, SP, 1972.

38. Espíndola ACS, Passos CO, Souza EDA, Santos RA. Avaliação do Grau de Sucesso e Insucesso no Tratamento Endodôntico em Dentes Uni-Radiculares. RGO, Rev Gaúch Odontol. 2002;50(3):164-166.

39. Fidel SR, Berlink TCA, Siqueira NL, Otero AS, Tavares OMR. Análise radiográfica da qualidade do tratamento endodôntico da clínica de endodontia da FO/UERJ. Rev Bras Odont. 1998;55(2):109-112.

40. Marques JLL, Silva JL, Pereira F, Safioti M, Lima LM. Análise radiográfica da qualidade do tratamento endodôntico e suas interações. Rev Bras Odont. 1997;54(1):11-15.

41. Couto, SDS, Milano, NF. Avaliação dos tratamentos endodônticos. Rev Gaúch Odontol. 1988;36(4):255-258.

42. Silveira FF, Moraes VR, Rodrigues DC. Avaliação de tratamentos Endodônticos em Acadêmicos da Faculdade de Odontologia da Universidade de Itaúna/MG. RGO 2002;50(3):133-136.

Received on: 30/11/2018 Final version resubmitted on: 20/2/2019 Approved on: 13/3/2019 